\author{
Тетяна Кулага, \\ аспірант кафедри теорії і методики музичної освіти та \\ хореографії, \\ Мелітопольський державний педагогічний університет \\ ім. Б. Хмельницького, \\ (м. Мелітополь, Україна) \\ Tetiana Kulaha, \\ postgraduate student of the Department of Theory and \\ Methods of Music Education and Choreography, \\ Melitopol State Pedagogical University named after B. \\ Khmelnytsky, \\ (Melitopol, Ukraine) \\ mmemsh1@ukr.net \\ ORCID ID 0000-0001-6116-7881
}

УДК 378.091.33:784.9:001.895

\title{
ІННОВАЦІЙНІ ІДЕЇ ВИКЛАДАННЯ ЕСТРАДНОГО ВОКАЛУ В КОНТЕКСТІ ВИРІШЕННЯ ПРОБЛЕМ ВІТЧИЗНЯНОЇ ВОКАЛЬНОЇ ПЕДАГОГІКИ
}

\begin{abstract}
Анотація. Стаття присвячена огляду зарубіжних досліджень останніх 20 років, що знаходяться у вільному доступі мережі Інтернет і використання досвіду яких здатне збагатити й оновити систему вітчизняної вокальної освіти. Дослідження проводилося з погляду принципу культуровідповідності та ґрунтувалося на холістсько-емерджентному, вітально-аксіологічному, праксіологічному, синергетичному й тезаурусному підходах, які актуалізують спрямування навчального процесу на активізацію творчого оволодіння відповідними компетентностями та розширення меж особистого досвіду. У статті окреслено проблеми сучасної естрадної вокальної педагогіки, а саме: відсутність цілісного систематизованого науково-методичного знання; використання переважно результатів досліджень, проведених ще в XX столітті; недостатня увага до досвіду зарубіжних вокальних педагогів та мистецтвознавців; академічна спрямованість та невідповідність змісту і рекомендованого репертуару рівню культури та її цивілізаційних перспектив в програмах для спеціалізованих музичних шкіл та шкіл мистецтв. У статті представлені результати досліджень, які стосуються: ролі педагога в освітньому процесі; інтеграції різних видів мистецтв; інноваційних методів навчання і видів музичної діяльності, що відповідають сучасному стану музичної і, зокрема, вокальної культури; особливостей голосоутворення і специфічних способів звуковидобування естрадного вокалу та способів оволодіння ними через традиційну техніку bel canto; критеріїв оцінювання результатів навчання естрадного вокаліста; доцільності введення джазу в сучасну програму навчання; питань естрадно-джазової інтерпретації та імпровізації. Результати дослідження можуть бути використані при розробці моделі формування естрадного вокально-виконавської тезауруса старшокласників закладів спеціалізованої музичної освіти.
\end{abstract}

Ключові слова: естрадний вокал; сучасна вокальна педагогіка; методологія; методика; інновації.

\section{INNOVATIVE IDEAS OF TEACHING POP VOCAL IN THE CONTEXT OF DECISION PROBLEMS OF UKRAINIAN VOCAL PEDAGOGY}

\begin{abstract}
The article is devoted to the issues of pedagogical interaction and methods of teaching pop vocal and it is an overview of modern foreign publications that are freely available on the Internet. The study conducted from the standpoint of cultural-conformity and based on vital-axiological, holistic-emergent, praxiological, synergetic and thesaurus approaches, which actualize the direction of the educational process to enhance the creative mastery of relevant competencies and expand the boundaries of personal experience. This article outlines the problems of contemporary pop vocal pedagogy, namely: the lack of a holistic systematic scientific and methodological knowledge; use mainly the results of research conducted as early as the twentieth century; insufficient attention to the experience of foreign vocal teachers and art historians; academic focus, non cultural-conformity of content and recommended repertoire in programs for specialized music schools and art schools. It presents contemporary opinions, suggestions and recommendations regarding the organization and content of the educational process with pop singers. This is the role of the teacher in the educational process; integration of various arts; innovative teaching methods and types of musical activity corresponding to the current tendenses of musical and, in particular, vocal culture; features of contemporary vocal techniques, specific vocal qualities and methods of mastering them through the traditional bel canto technique; competencies necessary for pop singers; criteria for evaluating the results of training of a pop vocalist; the appropriateness of introducing jazz into a modern curriculum; issues of pop\&jazz interpretation and improvisation. The article provides a description of non-traditional approaches characteristic of informal education and emphasizes promising of introducing them into a specialized art education. It is noted that the results of this study can be used in the development of a model for the formation of a pop vocal-performing thesaurus of high school students of institutions of non-formal specialized music education.
\end{abstract}

Keywords: pop vocal; contemporary vocal pedagogy; methodology; methods; innovations. 


\section{ВСТУП}

Постановка проблеми. Естрадний вокал як різновид сольного співу є мистецтвом особистісним і творчим. Він сприяє виявленню індивідуальних задатків, розкриттю та розвитку інтелектуальних і творчих здібностей, що активно впливає на естетичне і моральне виховання та формування особистості в цілому. Різні музичні шоу, конкурси, фестивалі, якими наповнений телевізійний ефір і мережа Інтернет, сприяють популяризації естрадного співу та пошуку виконавцями нових засобів для досягнення максимального результату. Але, незважаючи на те, що на сучасному етапі розвитку української незалежної держави відбувається активне оновлення музичної освіти, теорія і методологія викладання естрадного вокалу, зокрема в закладах спеціалізованої музичної освіти, тільки починає формуватися, як і естрадне мистецтво в цілому, яке, згідно з В. Откидач, «знаходиться ще в тому періоді свого розвитку, коли визначеність контурів тільки вимальовується, роди та жанри формуються, перевіряються часом, уточнюються їх функціональні особливості» (Откидач В., 2013, с. 17).

Аналіз наукових досліджень і публікацій. До недавнього часу вітчизняні дослідження методики викладання сучасної музики стосувалися інструментального мистецтва. Сучасний вокал розглядається тільки протягом останніх 15-20 років, на відміну від США, де з 1970-х років попереднього століття в коледжах і університетах почали пропонувати навчання співу МТ (музичний театр), який містить всі характерні риси сучасного вокалу і охоплює всі жанри некласичної вокальної музики.

У даний час існують досить яскраві роботи українських дослідників Д. Бабич, А. Довгань, Н. Дрожжиної, Л. Каменецкої, Л. Коваль, А. Павленко, В. Плахотнюка, Г. Постевки, Т. Самої, В. Славіної, Г. Цзинхен, Л. Червонської, С. Чернікової, А. Чечі тощо з питань естрадної вокальної освіти. Однак слід зазначити, що вітчизняні вчені спираються переважно на результати досліджень, проведених ще в XX столітті і недостатньо використовують досвід зарубіжних вокальних педагогів та мистецтвознавців, а їx дослідження стосуються окремих аспектів навчання естрадному вокалу і не виявляють цілісного систематизованого науково-методичного знання. До того ж аналіз програм для спеціалізованих музичних шкіл та шкіл мистецтв, а також спілкування з вокальними педагогами дають можливість констатувати, що сучасні вітчизняні методики навчання естрадному вокалу, по-перше, мають переважно академічну спрямованість; по-друге, в них не враховуються реалії сучасної музичної культури; по-третє, пропонований в них репертуар не відповідає часу і бажанням сучасного молодого покоління; по-четверте, в них не приділяється належної уваги питанням стилістики, музичної мови і специфічних вокальних технік сучасного некласичного вокалу.

\section{МЕТА І ЗАВДАННЯ ДОСЛІДЖЕННЯ}

У світовій педагогічній думці проблематика естрадної вокальної освіти в останні роки розглядається досить активно, що й актуалізує мету даної статті, що може бути сформульована як надання додаткової інформації з питань естрадної вокальної педагогіки, яку доцільно використовувати в процесі формування естрадного вокально-виконавського тезаурусу учнів старших класів закладів спеціалізованої музичної освіти України.

\section{РЕЗУЛЬТАТИ ДОСЛІДЖЕННЯ}

За межами України питання організації педагогічної взаємодії висвітлюють А. Богдзевич, С. Бордман, Р. Вайсберг, Р. Вуді, П. Джонс, Ж. Дурлак, А. Іванова, Дж. Мрозіак, А. Назіна, М. Паша, М. Степанов та інші вчені. Проблемам методики навчання естрадному вокалу присвячують дослідження Е. Бонацці, В. Боумен, Т. Борн, Б. Вінні, Л. Грін, П. Грейг, Д. Каток, Б. Кемпфер, Г. Купер, В. Сайн, К. Седолін , Дж. Слобода, А. Уеллс, Р. Флемінг-ДеБергер, Г. Холлі, Л. Хрестіансін, Т. Хьюгес, Р. Едвін, А. Еддісон та інші.

Естрадна музика є мистецтвом більше практичним, ніж теоретичним, і вимагає продуктивних методів навчання, тому, на мій погляд, слід звернути увагу на публікацію А. Богдзевіч зі співавторами, які відзначають, що в сучасній неформальній освіті викладача замінює тренер або модератор, який підтримує і координує процес навчання і його роль полягає не в передачі знань, а в створенні і підтримці умов, що сприяють оптимізації процесу навчання (Богдзевич А., 2009, с. 10). Основними завданнями вчителя, на наш погляд, повинно стати спрямування навчальної діяльності на особисте дослідження учнем свого вокального апарату, діагностування вокальних труднощів, які в нього виникають, та надання йому методів подолання цих труднощів.

Використовуючи принципи естетичного виховання, критичної педагогіки та технологічного педагогічного змісту, Дж. Мрозіак пропонує інноваційну освітню технологію, в якій «учень розміщується в центрі змістовного, автентичного досвіду мистецької освіти» (Mroziak J., 2017, с. 167), в якому пропонується особистісний шлях до навчання, що виходить за межі єдиної дисциплінарної точки зору й використовуються методи взаємодії, діалогу, творчості та особистісної ідентичності й емпатії, яка вимагає від учнів розуміння і втілення досвіду інших як емоційно, так і інтелектуально. Ця технологія дає можливість викладачам «брати участь в тому, щоб допомогти учням стати тими, ким вони ще не є» (Mroziak J., 2017, с. 169). При цьому дуже важливо, з одного боку, враховувати потреби, переваги і бажання дітей, а з іншого, - гранити їх (як алмаз), за необхідності коригувати і спрямовувати вектор їх розвитку.

Музичний навчальний план XXI століття, вважає П. Джонс, по-перше, повинен зв'язати учнів з музичним середовищем, в якому вони живуть, а музичні події повинні підкреслювати музику, яку вони знайдуть в своїх громадах, надаючи можливість учням їі виконувати; по-друге, підготувати учнів до боротьби з маніпулюванням музикою в рекламі, торгових центрах і місцевих магазинах (Jones P., 2004, с. 12-130). Автор пропонує оригінальну програму, в якій учні «розробляють виконавські навички, аналітичні, критичні і композиційні вміння, які вони можуть використовувати поза школою, незалежно від будь-якого музичного “експерту", який ними керує. Кінцевим результатом має бути незалежна музика» (Jones P., 2004, с. 14). Також автор рекомендує оснащувати індивідуальні та групові аудиторії технологіями, необхідними для супроводу, запису і відтворення музики (Jones P., 2004, с. 15).

Вчені Американської академії вокальних педагогів (англ. - American Academy of Teachers of Singing) зазначають, що викладачі повинні поважати будь-який стиль, якому вони вчать, використовувати характерні для кожного 3 них 
засоби виразності і вокальні техніки і не намагатися змінити стиль, тим самим «компрометуючи цілісність жанру і вміння співака успішно конкурувати в ньому» (Addison A., 2008, с. 10) не тому, що одна техніка або стиль кращі, ніж інші, а тому, що вони різні естетично, фізіологічно і акустично, отже, вимагають різних педагогічних підходів.

В. Боумен зазначає, що побоювання щодо недоліків популярної музики, які проголошуються деякими класичними педагогами, «не повинні тримати її поза школою: по-перше, вона не є дефектною чи недостатньою; по-друге, однією з проблем освіти є поліпшення доступу людей до того, що допоможе зробити їх більш усвідомленими в сприйнятті і виборі. Освіта дійсно може актуалізувати поліпшення якості популярної музики, роблячи учнів більш обізнаними і компетентними» (Bowman W., 2004, c. 40).

Ж. Дурлак і А. Уеллс (Durlak J. \& Wells A., 1997) рекомендують використовувати активні методи навчання, тобто після того, як учень отримає основні вказівки, необхідно дати йому можливість «практикувати нову поведінку і отримувати зворотний зв'язок про свою роботу (Durlak J. \& Wells A., 1997, с. 296), «цикл практики і зворотного зв'язку триває до досягнення майстерності» (Durlak J. \& Wells A., 1997, c. 296).

У дисертації С. Бордман «Voice Training for the Musical Theater Singer» визначено завдання вокальної освіти, які в українській педагогіці поки не отримали належної уваги, а, наш погляд, мають велику цінність для організації повноцінного процесу навчання естрадному вокальному мистецтву. До них автор відносить інтеграцію мови, співу і навичок руху; володіння тілом; звільнення голосу; розвиток емоцій і уяви; розуміння і відчуття музики й ритму на глибокому фізичному і психічному рівнях тощо (Boardman S., 1987, с. 88-96).

Про необхідність розробки нової системи вокальної педагогіки, заснованої на синергії різних жанрів і стилів наполягають багато вчених з усього світу. Зокрема, Б. Вінні вважає, що співакам необхідно бути гнучкими у створенні «здорового» вокалізму, який відповідає сучасним вокальним стилям і жанрам. Важливо розуміти, що жодна з вокальних якостей не є ексклюзивною для певного некласичного жанру, а їх елементи можуть використовуватися в будь-яких стилях і в різних комбінаціях. У свою чергу, основні положення bel canto використовуються в сучасній вокальній техніці (СВТ) «з різними вокальними механістичними змінами в кожній з якостей» (Winnie B., 2014, с. 30). До того ж, вокалісту необхідно чітко усвідомлювати специфічні способи звуковидобування, такі як оральний і нозальний «twang» (вокальний дзвін) в кантрі, «wail» (стогони) в соул, «rasp» (розщеплений звук) в стилі рок тощо (Addison A., 2008, с. 10).

Т. Борн зі співавторами демонструють істотні і специфічні відмінності між класичним і МТ вокальним виробництвом; проблеми вокального здоров'я для МТ співаків; сучасні знання про фізіологічні і акустичні елементи звуковидобування, специфічні для співу МТ; результати голосової науки щодо вокального виробництва МТ; інформацію про реєстрацію з включенням белту; тренувальні вправи і рекомендації про підходи до «здорової» вокальної підготовки (Bourne T., Garnier M. \& Kenny D., 2011, с. 441-442).

Один із відомих дослідників сучасного вокалу Р. Едвін пропонує перехресну постановку голосу на основі використання техніки bel canto і СВТ, яка дає можливість знаходити способи досягнення результату в сучасному вокалі через традиційні академічні методики (Edwin R., 2008). Автор визначає різницю голосової техніки в сучасному вокалі і пропонує цікаві методи її формування, наприклад, порівняльну вокализацию (академічну і сучасну) для відчуття різниці в звуковидобуванні в різних стилях, плавний перехід з мови до співу тощо (Edwin R., 2008, c. 71). При виконанні класичних творів він пропонує знижувати гортань, збільшувати глотку, відкривати рот і піднімати м'яке піднебіння, а в сучасних творах злегка піднімати гортань, звужувати глотку і знижувати м'яке піднебіння при відкритому положенні рота (Edwin R., 2000, с. 73). Стиль, на його думку, «інформується вокальною технікою, створенням характеру, використанням відповідної мови, кругозором, традиційними очікуваннями аудиторії і, мабуть, найважливіше, бажанням розповісти історію чесно і захоплююче» (Edwin R., 2008, с. 72).

Використовуючи одночасно різні методи донесення навчальної інформації, такі як: анатомічні пояснення, фізичні інструкції, приклади «саунду» на CD, ілюстрації і опис суб'єктивного сприйняття внутрішніх образів і відчуттів, - К. Садолин пропонує практичні рекомендації з оволодіння:

1) основами вокального виробництва (відкрите горло, підтримка дихання, ненапружені м'язи щелепи і формування голосних, не сильно змінюючи форму рота);

2) чотирма вокальними режимами - нейтральний (Neutral); напівметалевий (Curbing), який звучить дещо тужливо або стримано, як колись ви стогнете від болю; металевий (Overdrive), який в традиційній музиці має назву грудного регістру; вокальний крик (Belting);

3) різними вокальними якостями, яких можна досягти, змінивши форму голосового тракту, форму воронки епіглоту, положення гортані, форми язика та рота, положення піднебіння, відкриття або закриття носового проходу тощо;

4) вокальними ефектами, такими як повна і часткова деформація звуку (full and half-distortion), деренчання (rattle), гарчання (growl), субтон (subtone), додавання дихання до вокальному звуку (breathiness), хрип або скрип (scream), діафрагматичне вібрато, техніка орнаментації (running) тощо (Sadolin K., 2008).

Автор вважає, що виконання технічних вправ повинно мати намічений ефект негайно, інакше тренування виконується неправильно, а практика повинна бути максимально наближена до реальної ситуації (наприклад, музиканти, які співають сидячи, повинні і тренуватись сидячи). К. Садолин пропонує вчитися співу зручно, радіючи і довіряючи своїм почуттям, а одним з основних завдань вчителя вважає допомогу співакові досягти бажаного звучання без шкоди для здоров'я, тобто розпізнавши м'язову напругу, пропонувати методи ії усунення. Вчитель, вважає автор, може також пропонувати різні варіанти «саунду», але співак повинен зробити свій власний художній вибір самостійно (Sadolin K., 2008, с. 9-11).

Прямий тон (англ. - straight tone) як мінімально відчутне резонансне і врівноважене вібрато, яке може використовуватися для поліпшення резонансу і фокусу, а також забезпечувати вихідну точку трансформації голосу, досліджує Д. Каток. Автор пропонує вокальні вправи, розроблені для виявлення вродженого основного звуку 
співака, який можна використовувати для визначення прямого тону, який «універсальний співак може модифікувати для досягнення палітри стилістичних фарб і ефектів для будь-якого жанру» (Katok D., 2016, c. 104).

Основні музичні характеристики фанку з точки зору взаємодії ритму і метру; основну для соулу і фанку музичну концепцію «Groove and Flow», яка відображається у використанні повторюваних музичних фігур (groove) для того, щоб сформувати почуття руху або потоку; парадокс колективної індивідуальності як однієї з найпотужніших сил, що формують американську популярну музику, та інше розглядає Т. Хьюгес (Hughes T., 2003).

Загальна тенденція до злиття європейської і неєвропейських культур, яка характерна для музики XX та XXI століть, виражається у вторгненні джазових інтонацій в європейське мистецтво, яке піднімає його на принципово новий щабель (Конен В., 1975, с. 417). Використання джазу в навчальних програмах з підготовки сучасних естрадних вокалістів, на наш погляд, активізує слухове сприйняття і розуміння, може допомогти в оволодінні основами теорії музики та концептуальними виконавчими навичками і дозволяє співакові бути неповторним, креативним і виразним. Однак, як зазначає В. Сайн, серед педагогів існує думка, що «джаз є сприйнятим, а не навченим» (Singh V., 2006, c. 47) і навчитися виконанню джазу можливо тільки з особистого досвіду викладача або копіюючи джазових музикантів. Це справедливо в тому контексті, що, по-перше, чітко і в подробицях записати інтонаційні, ритмічні і сонорні особливості джазового виконання засобами сучасної нотації неможливо; по-друге, джаз для європейців не є сприйнятним на генетичному рівні; по-третє, на даний момент відсутній загальноприйнятий категоріальнопонятійний апарат цього жанру музичного мистецтва, що зумовлює складність у формуванні теоретичної бази естрадно-джазової педагогіки. 3 іншого боку, педагогу-вокалісту, який працює з естрадними і джазовими співаками, необхідно мати на увазі, що вокалісти-початківці в силу недостатності власного досвіду не в змозі самостійно розібратися в особливостях музичної мови і методах оволодіння ними. Тому необхідною умовою плідної педагогічної діяльності в даному жанрі є глибоке розуміння його специфіки та вміння донести їі зрозумілою і доступною для кожного учня мовою. Важливими для розвитку навичок джазового музикування факторами, вважає Дж. Слобода, є «можливість брати участь в спільних джазових заходах, де допускаються помилки, і де можна вибрати рівень ризику і складність своєї роботи» (Sloboda J., 1990, с. 174).

Посилаючись на досвід власного становлення і розвитку в якості вокаліста музичного театру, Г. Холлі визначає необхідні компетентності в цій сфері, а саме: володіння стилями; тверде розуміння того, як голос працює як в класичних, так і в сучасних жанрах; розвинені технічні навички і вміння застосовувати специфічні «вокальні якості» відповідно до обраного стилю; використання повною мірою свого діапазону і розвиток його через різні вокальні стилі; довговічність голосу і вокальна стійкість; універсальність в багатьох сферах співу, танцю та акторської майстерності; стійкість до успіху, критики й здатність вчитися на коментарях; вміння експериментувати з такими областями, як монолог, імпровізація, комедія тощо (Holley G., 2016, c. 94-97).

Р. Флемінг-Де-Бергер пропонує критерії оцінювання результатів навчання в сучасному вокалі. У процесі аналізу їі дослідження були виділені доцільні для використання в спеціалізованій музичній освіті критерії, які відповідають сучасним вокальним стилям, а саме: розуміння і вміння здорового грудного, змішаного і головного голосоутворення і доречності використання кожного з них відповідно до стилю твору; здатність співати з мовним резонансом і артикуляцією; гнучкість і підтримка єдиного вокального виробництва при переході між промовою і співом; рівень навичок роботи над твором; інтерпретація; знання репертуару і стилів МT; розуміння і вміння виконувати твори в максимальній кількості музичних стилів; розуміння відповідності вокального виробництва характеру твору; здатність аналізувати музику, тексти і синтезувати всі сфери діяльності і знання (Fleming-DeBerger R., 2011, с. 76-79).

Естрадне i, особливо, джазове мистецтво передбачають наявність індивідуальності і непередбачуваності у виконанні творів будь-якого стилю, чого неможливо зробити за недостатнього рівня самостійності й можливості експериментувати в «пошуках» свого особистого «саунду» і манери виконання. Тому вважаємо, що дослідження Л. Грін, в якому автор описує деякі суттєві відмінності в інструментальних і технологічних навичках, груповій взаємодії, поглядах і цінностях поп-музикантів від 15 до 50 років, які мають досвід інформального навчання, можуть збагатити українську вокальну педагогіку деякими нетрадиційними підходами, наприклад:

1) позитивне сприйняття процесу розвитку музичного слуху, музичної пам'яті та музичного мислення шляхом особистісно-цінного музикування із застосуванням музики, яка подобається учням і яку вони чітко ідентифікують;

2) практичне ознайомлення зі стилістичними особливостями творів від «носіїв» кожного окремого стилю музики, а не з розповіді викладача через усвідомлене і неусвідомлене навчання, що включає дискусію, спостереження, слухання та імітацію;

3) активізація самонавчання та творчої самореалізації, які відбуваються шляхом інтеграції слухання, виконання, імпровізації і композиції тощо (Green L., 2013).

Вищезазначене і власний виконавський досвід дає можливість вважати, що використання певних складових «нерегламентованої» інформальної освіти має великий практичний потенціал для поліпшення змісту вітчизняної естрадної вокальної педагогіки.

\section{ВИСНОВКИ ТА ПЕРСПЕКТИВИ ПОДАЛЬШИХ ДОСЛІДЖЕНЬ}

Таким чином, проаналізувавши іноземні джерела в сфері естрадної вокальної педагогіки, можна констатувати, що в світовій педагогіці існують ґрунтовні теоретичні й практичні дослідження з питань методології та методики навчання мистецтву сучасного естрадного вокалу. Тому актуальним є вивчення зарубіжного досвіду та його впровадження в розробку моделі формування сучасного естрадного вокально-виконавського тезаурусу учнів старших класів закладів спеціалізованої музичної освіти. 


\section{СПИСОК ВИКОРИСТАНИХ ДЖЕРЕЛ}

Addison, A., Bonazzi, E., Christiansen, L., Craig, P., Douglas, J., Edwin, R., Emmons, S. \& Others (2008). In Support Of Contemporary Commercial Music (Nonclassical) Voice Pedagogy. Journal of Singing, 65 №1, p. 7-10.

Boardman, S. (1987). Voice Training for the Musical Theater Singer. DMA Thesis. University of Cincinnati. Cincinnati.

Богдзевич, А., Иванова, О., Назина, А., Степанов, М. (2009). Тренер - группа - семинар: другой путь образования молодежи, Берлин: Коллегия им. Теодора Хойсса, фонд им. Роберта Боша, MitOst, 139 c.

Bourne, T., Garnier, M., Kenny, D. (2011). Music Theater Voice: Production, Physiology and Pedagogy, Journal of Singing, 67 №4, pp. 437-444

Bowman, W. (2004). Pop' Goes...? Taking Popular Music Seriously. In Rodriguez C. (Ed.). Bridging the gap: popular music and music education. Reston, VA: MENC, pp. 29-49.

Durlak, J., Wells, A. (1997). Primary Prevention Mental Health Programs For Children And Adolescents: A Meta-Analytic Review, American Journal of Community Psychology, 25, p. 115-152.

Edwin, R. (2008). Cross training for the voice, Journal of Singing, 65, №1, pp. 73-76.

Edwin, R. (2000). From Classical to Pop: A Case Study, Journal of Singing, 56, №3, pp. 71-72.

Fleming-DeBerger, R. (2011). Guidelines And Criteria To Assess Singing And Music Training In Baccalaureate Music Theater Programs. Doctoral thesis. University Of Miami, Coral Gables. Florida.

Green, L. (2013). How Popular Musicians Learn. A Way Ahead for Music Education, London: Ashgate Publishing, Ltd.

Holley, G. (2016). From Classical to Music Theatre: A Vocalist's Experience. Doctoral thesis. Queensland Conservatorium. South Brisbane.

Hughes, T. (2003). Groove and Flow: Six Analytical Essays on the Music of Stevie Wonder. Doctoral thesis. University of Washington. Washington.

Jones, P. (2004). Returning music education to the mainstream: Reconnecting with the community. Conference; 26TH, International Society for Music Education: Sound worlds to discover. Tenerife, Spain, Madrid: Enclave Creativa Ediciones, p. 38-57.

Katok, D. (2016). The Versatile Singer: A Guide to Vibrato \& Straight Tone. Doctoral thesis. The City University. New York.

Конен, В. (1975). Этюды о зарубежной музыке, Москва: Музыка, 480 с.

Mroziak, J. (2017). Exiles on Main Street: A Pedagogy of Popular Music Through Technology and Aesthetic Education. Doctoral thesis. Duquesne University. Pittsburgh.

Откидач, В. (2013). Естрадний спів і шоу-бізнес : навч.-метод. посіб., Вінниця: Нова Книга, 368 с.

Sadolin, K. (2008). Complete Vocal Technique. New South Wales, Australia: Shout Publications.

Singh, V. (2006). Advocacy for Jazz Pedagogy: Where to Find Resources and Quality Teaching Tools. Choral Journal, 47, №3, pp. 47-51.

Sloboda, J. (1990). Musical excellence - how does it develop. Encouraging the development of exceptional skills and talents, pp. 165-178.

Winnie, B. (2014). Contemporary vocal technique in the choral rehearsal: Exploratory strategies for learning. Doctoral thesis. University of Washington. Washington.

\section{REFERENCES}

Addison, A., Bonazzi, E., Christiansen, L., Craig, P., Douglas, J., Edwin, R., Emmons, S. \& Others (2008). In Support Of Contemporary Commercial Music (Nonclassical) Voice Pedagogy. Journal of Singing, 65 №1, p. 7-10.

Boardman, S. (1987). Voice Training for the Musical Theater Singer. DMA Thesis. University of Cincinnati. Cincinnati.

Bogdzevich, A., Ivanova, O., Nazina, A., Stepanov, M. (2009). Trener - gruppa - seminar: drugoj put' obrazovanija molodezhi (Trainer - group seminar: another way of youth education). Berlin: Kollegija im. Teodora Hojssa, fond im. Roberta Bosha, MitOst, $139 \mathrm{~s}$.

Bourne, T., Garnier, M., Kenny, D. (2011). Music Theater Voice: Production, Physiology and Pedagogy, Journal of Singing, 67, №4, pp. 437-444.

Bowman, W. (2004). Pop' Goes...? Taking Popular Music Seriously. In Rodriguez C. (Ed.). Bridging the gap: popular music and music education. Reston, VA: MENC, pp. 29-49.

Durlak, J., Wells, A. (1997). Primary Prevention Mental Health Programs For Children And Adolescents: A Meta-Analytic Review, American Journal of Community Psychology, 25, p. 115-152.

Edwin, R. (2008). Cross training for the voice, Journal of Singing, 65, №1, pp. 73-76.

Edwin, R. (2000). From Classical to Pop: A Case Study, Journal of Singing, 56, №3, pp. 71-72.

Fleming-De-Berger, R. (2011). Guidelines And Criteria To Assess Singing And Music Training In Baccalaureate Music Theater Programs. Doctoral thesis. University Of Miami, Coral Gables. Florida.

Green, L. (2013). How Popular Musicians Learn. A Way Ahead for Music Education, London: Ashgate Publishing, Ltd.

Holley, G. (2016). From Classical to Music Theatre: A Vocalist's Experience. Doctoral thesis. Queensland Conservatorium. South Brisbane.

Hughes, T. (2003). Groove and Flow: Six Analytical Essays on the Music of Stevie Wonder. Doctoral thesis. University of Washington. Washington.

Jones, P. (2004). Returning music education to the mainstream: Reconnecting with the community. Conference; 26TH, International Society for Music Education: Sound worlds to discover. Tenerife, Spain, Madrid: Enclave Creativa Ediciones, p. 38-57.

Katok, D. (2016). The Versatile Singer: A Guide to Vibrato \& Straight Tone. Doctoral thesis. The City University. New York.

Konen, V. (1975). Jetjudy o zarubezhnoj muzyke (Studies on foreign music), Moskva: Muzyka.

Mroziak, J. (2017). Exiles on Main Street: A Pedagogy of Popular Music Through Technology and Aesthetic Education. Doctoral thesis. Duquesne University. Pittsburgh.

Otkydach, V. (2013). Estradnyi spiv i shou-biznes : navch.-metod. posib. (Pop singing and show business : A Manual). Vinnytsia: Nova Knyha.

Sadolin, K. (2008). Complete Vocal Technique. New South Wales, Australia: Shout Publications.

Singh, V. (2006). Advocacy for Jazz Pedagogy: Where to Find Resources and Quality Teaching Tools. Choral Journal, 47, №3, pp. 47-51.

Sloboda, J. (1990). Musical excellence - how does it develop. Encouraging the development of exceptional skills and talents, pp. 165-178.

Winnie, B. (2014). Contemporary vocal technique in the choral rehearsal: Exploratory strategies for learning. Doctoral thesis. University of Washington. Washington. 